\title{
The disempowerment of early childhood practitioners in impoverished and marginalised communities
}

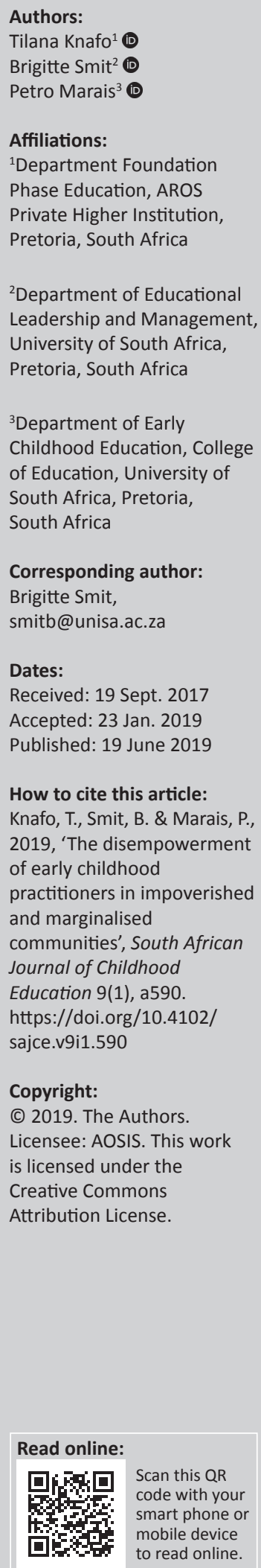

Background: Quality early childhood programmes have proven to be highly cost-effective in reversing the detrimental consequences of poverty on children's development. However, these programmes can only influence developmental outcomes of poor children if their needs are considered.

Aim: The purpose of this article was to inquire into the experiences of two early childhood development (ECD) practitioners working and living in impoverished and marginalised predominantly white communities where the involvement of volunteers from charity organisations was prominent. The researchers argued that the practitioners' experiences regarding their work should inform the kind of complementary volunteer aid and support sought for.

Setting: The research sites were two informal predominantly white settlements where unemployed residents lived in makeshift housing.

Methods: A narrative inquiry, nested in the social constructivist paradigm, was employed to explore the experiences of two practitioners. Data were collected from narrative interviews, observations, documents, photographs and artefacts.

Results: Both participants knew well that the needs of the children in their care differed significantly from those of their more affluent peers and believed that training would equip them better for their task. Although both centres (and communities) benefitted from volunteer support, this well-intended aid was often misguided as the volunteers were not qualified educators and did not understand the context.

Conclusion: The volunteers did not empower the practitioners to use their insight and experience to deliver a quality programme fit for context. Instead, they left the practitioners with a sense of disempowerment by dictating the programmes and practices to be followed in the respective ECD centres, even though they were not qualified to do so.

Keywords: early childhood development practitioners; impoverished and marginalised communities; informal settlements; narrative inquiry; volunteer support.

\section{Introduction}

The United Nations stated the universal termination of poverty in all its forms as the first of its 17 Sustainable Development Goals identified by the organisation in 2015 (United Nations 2015). Also, Statistics South Africa (2015) regards the eradication of poverty as one of the most pressing issues to be addressed. Poverty is a complex chronic and debilitating condition. A plethora of literature since the 1960s has shown its negative impact on all aspects of a child's development (Brooks-Gunn \& Duncan 1997; Jensen 2009; Mustard 2007; Shonkoff \& Phillips 2000).

In spite of this bleak scenario, leading economists such as Heckman (2013), Bernanke (2012), Grunewald (2015) as well as the World Bank publication No Small Matter: The Impact of Poverty, Shocks, and Human Capital Investments in Early Childhood (Alderman 2011) regard quality early childhood development (ECD) programmes to be one of the most efficient ways to level the playing field between the haves and the have-nots. At the same time, Grunewald (2015) warns against poor quality of ECD programmes, which he believes creates excessive stress that is detrimental to the healthy development of children. Therefore, programmes catering for poor children should be tailored to address their needs to be developmentally appropriate and efficient (Azzi-Lessing 2010).

For this reason, ECD practitioners serving these children and their families need to be empowered to develop and present a suitable programme. Practitioners experience the needs of the children in their care on a daily basis. They also intimately understand the social conditions of their 
communities, which, in turn, influence the development of their children. Therefore, their experiences should be a primary consideration when designing a quality ECD programme for children from impoverished backgrounds. Regarding the empowerment of unqualified practitioners in township centres, Fourie (2013) recommends practitioner participation in the development of their skills and knowledge. In this regard, Fourie (2013:61) refers to 'teaching and learning experiences that are transactional'.

Some significant studies have been conducted on early childhood programmes in predominantly black informal settlements and impoverished rural areas (Dawes, Biersteker \& Hendricks 2012; Ebrahim, Killian \& Rule 2011; Van der Vyver 2012). Insights emanating from such studies contribute to a better understanding of the context and needs of ECD centres in these communities. However, no scholarly studies on ECD programmes in informal settlements of predominantly white people could be found. This observation was confirmed by Dr Danie Brink, executive director of Solidarity Helping Hand (a non-government organisation [NGO] whose focus is primarily on the plight of poor white people) during a personal communication in 2015.

This article is based on a study of the experiences of two ECD practitioners working and living in impoverished predominantly white informal settlements (Knafo 2016). The broader study was guided by four questions:

- What are the experiences of the practitioners regarding the children in their care?

- What are the experiences of the practitioners regarding the parents of the children in their care?

- How do the practitioners' personal issues have an effect on their work?

- How do the experiences of the practitioners regarding their contexts influence the quality of their work?

Although the practitioners were not qualified, they showed remarkable dedication and insight regarding their work. Yet, a sense of disempowerment in their lives and work emerged as an ever-present theme in the stories of the participants. The two centres were supported by various volunteers from charity organisations and churches in terms of material support, and also in organising and running the centres. This state of affairs informed the fourth question above. This article now focuses explicitly on the last question.

The research focus is therefore on the degree of empowerment as experienced by the practitioners as a result of the various external influences and their particular context to work ethics.

\section{Theoretical framework}

This study has been conducted within Bronfenbrenner's ecological systems theory (1979) as theoretical framework. He identified four spheres of influence in a person's ecological system: micro-, meso-, exo- and macrosystems. The microsystem is described by Bronfenbrenner as the most direct and immediate sphere of influence on a person. The exosystems are those settings which may influence a person, although the person is not directly involved in the settings. The overarching circle of the ecological system, the macrosystem, consists of the belief systems, customs, hazards, life-course options, lifestyles and material resources of a particular culture or sub-culture. Bronfenbrenner's theory is frequently used in studies on childhood poverty, for example, Brown, Ackerman and Moore (2013) and Martin, Gardner and Brooks-Gunn (2012), to conceptualise the proximal and distal influences on children's development. This article assumes the point of view that the practitioners' experiences are determined by the entire ecological system in which the practitioner and child live and develop. At the same time, their experiences are not viewed as objective truths 'out there', but are seen as constructions of the practitioners' lived and subjective experiences.

\section{Literature review}

To understand the experiences of the ECD practitioners working in poverty, the nature of poverty should first be explored. Poverty is not merely a lack of income, but a multi-faceted concept, experienced by the poor as deprivation in various domains of their lives (Statistics South Africa 2014). At the same time, it is evident from the literature on poverty that each domain of deprivation contributes to a sense of marginalisation experienced by those trapped in the poverty cycle.

Marginalisation as an aspect of poverty is defined as 'being in a marginal or peripheral position from the centre of the main development activities or decision-making processes' (Executive Secretariat of the Africa Forum 2010:10). John Tesha, executive secretary of the Africa Forum (pers. comm., 2015), describes multiple deprivation and marginalisation as two sides of the same coin. Each domain of deprivation adds to the marginalisation experienced by the poor.

From the literature on poverty, it is evident that the poor are socially and physically marginalised. Ridge (2011) identifies limited and unaffordable transport and low-quality housing as contributing to their isolation. Friends are reluctant to visit cold and cramped homes. As the poor are embarrassed about their poverty, they try to hide it which further isolates them (Solidarity Helping Hand 2010). They are pushed to the outskirts of their communities because of unemployment and job losses. This, in turn, leads to stigmatisation of their neighbourhoods. As their physical space is removed from economic activities, the poor are disconnected from employment prospects (Angélil \& Siress 2012; Šabić et al. 2013). Šabic et al. (2013:72) refer to these settlements as the 'invisible part of the city'. It is an ugly face characterised by neglect, unhygienic conditions, lack of sanitation and electricity, hidden from the eyes of tourists and foreign visitors.

The potential research sites (impoverished communities of predominantly white people) considered for this study were on farms, on smallholdings or in derelict caravan 
parks far from job opportunities, thus being geographically marginalised. Social woes such as child neglect and abuse, abandoned newborn babies and teenage prostitution characterise these settlements (Solidarity Helping Hand 2010). People live in wooden huts, caravans, corrugated iron shacks, chicken pens, under bridges and plastic sheets (Solidarity Helping Hand 2010). Extreme poverty seems to have a marginalising effect on all its victims. During this investigation, we learnt that the white residents of informal settlements and the aid organisations active in these settlements believe that they also have unique challenges. The perception exists, correctly or incorrectly, that white people do not have access to state and other forms of support, even though affirmative action deprived them of job opportunities. Research conducted on behalf of the Umsobomvu Youth Fund by Robin Pharoah (2008) found that these communities have largely fallen through the cracks of the current system. For example, they do not know about programmes available to them and for this and various other reasons do not access these programmes. It is evident that not only their immediate environment (the microsystem) but also more distal influences (the view of the more affluent and socially healthy part of society regarding the poor) contribute to a sense of marginalisation of these communities. The belief of impoverished white people regarding the macrosystem (a socio-political dispensation that does not support them) further pushes them to the fringes of society.

As indicated in the Introduction, a quality ECD programme is a highly effective route out of the poverty cycle. Nevertheless, poor parents in marginalised communities cannot access traditional ECD facilities because of distance and their inability to pay school fees (Atmore, Van Niekerk \& Ashley-Cooper 2012). Being socially, physically and economically segregated, an ECD centre in the community is the most logical arrangement to serve these families. However, the developmental needs and challenges of marginalised poor communities should play a crucial role in the design of ECD services (Fourie 2013). Therefore, Fourie (2013) emphasises that community members should participate in the design of a suitable programme. They are in the best position to give a realistic picture of everyday realities in the community. Accordingly, this article argues that the ECD practitioners working and living in impoverished and marginalised communities should play a central role in the design and presentation of a suitable programme. Yet, the literature shows that outsiders initiate, develop and manage these programmes (Fourie 2013). The approach of outside developers is described by Fourie (2013:61): 'Developers often think that they know best and therefore their prime function is to transfer knowledge to communities whom, by definition, know less'. Also, Kholowa and Rose (2007) point out that internationally accepted best practices might not be the most appropriate for every context. Early childhood development practitioners working in impoverished areas in Malawi indicated lack of training, limited resources and limited community contributions as daily challenges. However, a more fundamental challenge was parental expectation. Parents expected the ECD centre to prepare their children to study successfully to escape from poverty. This focus on academic skills is in contrast with a universal view of the holistic development of the young child. Yet, Kholowa and Rose (2007:458) believe that this parental perspective points to 'a greater awareness of local realities'.

Narrative inquiry was selected as a research design to explore the experiences of ECD practitioners working in these settlements, facilitating emotional responses from the research participants (Elliot 2005).

\section{Research design and methodology}

The study was concerned with the participants' understanding of the world in which they live and work. Creswell (2013) in this regard endorses that this view is shaped through their interaction with others. Therefore, it was necessary to understand the social context and complexities of the participants' experiences. Thus, the research approach was qualitative and narrative inquiry, nested in the social constructivist paradigm, was the design type. A narrative inquiry based on Dewey's (1938) notion of experience as research design was considered to be most appropriate, as 'experience' is the core of this study. Dewey explains that 'experience' creates social reality and from this ontological assumption, all inquiry follows (Clandinin \& Rosiek 2007). Accordingly, Caine, Estefan and Clandinin (2013) speak about a relational ontology in this regard. The narrative inquirer studies the experiences of the participants through their storied lives. At the same time, the cultural, historical, social and institutional narratives within which individual experiences are shaped and developed are also considered an important source of knowledge and understanding (Clandinin \& Rosiek 2007). For this study, the socio-political narratives regarding 'white squatter camps' within the broader South African context were explored. However, the experiences of the participants were the start and end points of the study.

A purposive sampling strategy was used to identify two practitioners (Rina and Thea, respectively) 1 in impoverished and marginalised communities of predominantly white people, who were information-rich and knowledgeable about the phenomenon (McMillan \& Schumacher 2010; Strydom \& Delport 2011). Rina worked as a practitioner alongside another practitioner - a volunteer from a church group. She was responsible for the younger group, whereas the volunteer taught the older group. The centre was managed by this volunteer as well as other volunteers. Thea, on the other hand, was appointed as a principal as well as a Grade R teacher by a volunteer (Mia) ${ }^{1}$ who started the centre in this community and also managed the centre. A few members of the community were appointed by the volunteer to work as practitioners for the younger age groups. The sample size was limited by the small population size, the availability of information-rich cases and the narrative 1.The names used are pseudonyms. 
interview as primary data collection technique as an in-depth understanding of their experiences was relevant. Christensen, Johnson and Turner (2015) expound the aim of purposive sampling to gain insight into a phenomenon and not to generalise findings from a sample to a population.

Gaining access to these communities was incredibly daunting. We had to approach two NGOs active in these communities to introduce us as a 'friend' of the community, because the members were wary of outsiders. We explained the purpose of the study to the manager of one of the settlements and the owner of the farm where the second settlement was established. Letters requesting the participation of the community in the study were explained and signed by the manager and the owner of the respective settlements. Letters of informed consent were signed by the two prospective participants after the purpose of the study as well as the significance of their contribution had been explained. We also secured ethical clearance from the College of Education of the University of South Africa.

The focus of this study was the experiences of Rina and Thea of their daily life and work as ECD practitioners in impoverished and marginalised communities of mostly white people. Data were collected using a variety of methods which allowed for a composition of richly descriptive field texts of the experiences of the participants. These included narrative interviews and conversations with the participants, field notes of non-participant observations, photographs, documents and artefacts.

Jovchelovitch and Bauer (2000) define the narrative interview as an unstructured in-depth interview used in qualitative research. The participant in a narrative interview is a storyteller who constructs the story on his or her terms and can develop or change the focus of the narrative according to his or her agenda (Hollway \& Jefferson 2008). The narrative interviews for this study were based on one question to the participants, to speak about their challenges and experiences regarding their work as ECD practitioners. This question elicited a response from the participants, but they owned the response. Their narratives were not only about their work but also about their settlement. They talked about their experiences not only with the children in the centre and their parents, but also with the community, their families and the outsiders and volunteers supporting the centre and the community. They talked about what they did before moving to the settlement, their present situation and their future plans.

The large volume of collected data was coded using 7 of the 32 coding techniques identified by Saldaña (2013). The steps recommended by Creswell (2013) and Butler-Kisber (2010) were followed to arrive at four themes, which became the major components of this study and write-up. Categories were constructed from the initial codes by comparing, combining, sorting and rearranging codes. These categories were then reduced and combined into four themes based on connections among the categories. The four themes were the practitioners' personal and social experiences, their experiences concerning place (their settlements), their experiences with camp leadership and their experiences concerning support infrastructure.

The data the participants provided the researchers to work with also left them vulnerable. The researchers therefore adhered to ethical measures such as informed consent, avoidance of harm, assurance of privacy, confidentiality, and anonymity and access to research texts. The researchers also tended to ethical issues specific to a narrative inquiry and dealt with these during the entire inquiry. Throughout the study, the researchers considered the observation of Elliot (2005) that the way a researcher analyses and interprets personal narratives may affect the participants. The researchers followed the recommendation by Berg (2009) to discuss the participants, their viewpoints, their settlements and their communities with sensitivity without compromising on honesty. The researchers followed Lieblich's advice (Clandinin \& Murphy 2007) to listen emphatically without judgement or disbelief. During the interviews and conversations with the participants, it was emphasised that because the researchers had never worked in similar conditions, their opinions could not be judged and that the participants were the experts in their contexts.

At the same time, the researchers endeavoured to establish the trustworthiness of this study in various ways, for example, to spend extensive time in the field with the participants to build a relationship of trust and to observe them in their natural environments (Butler-Kisber 2010; Creswell 2013; Lincoln \& Guba 1985; Schurink, Fouché \& De Vos 2011); to record interviews electronically and to jot down detailed observations on the spot (Strydom 2011) and to use various forms of field texts and data collection strategies to create thick descriptions (Butler-Kisber 2010; Creswell 2013). As the focus of the study was the experiences of the participants, their voices were conspicuous throughout the study (Butler-Kisber 2010).

\section{Ethical considerations}

Ethical clearance was obtained from the University of South Africa (Ref no.: 2014/September//MC).

\section{Findings}

Although the two communities where the study was conducted were similar, they were also different in many respects. Both were communities of mostly unemployed homeless individuals who lost their jobs, who were too sick or unqualified to work and even people who fled from the law. Many of the residents suffered from social ills that often accompany a life of poverty, such as alcohol and drug abuse, domestic violence and physical and sexual abuse, as described by Azzi-Lessing (2010), Waldfogel, Craigie and Brooks-Gunn (2010), Solidarity Helping Hand (2010) and Jensen (2009). 
Rina's settlement was a classic informal settlement, such as defined by Huchzermeyer and Karam (2006) as land illegally occupied as living space by the urban poor where any homeless person could squat. Thea's community, on the other hand, lived in a legal settlement on a privately-owned farm where the farmer erected wooden huts for unemployed and homeless families. Housing in both settlements was substandard and not conducive to the physical and social well-being of the residents. Although Rina's settlement was characterised by neglect and littering, the gardens in Thea's settlement were well tended to. Poverty and an accompanying sense of desperation compromised parents' capacity for positive parenting in both settlements.

The two participants came from vastly different backgrounds and had different histories that brought them to their respective settlements. Rina was a married woman with four children in her late 30s. She had completed her high school education and worked in an administrative position in a big city council until both she and her husband became unemployed and the family was evicted from their house for their inability to pay rent. The family ended up in the settlement. Rina desperately wanted to move away as she believed that settlement life was not a dignified way to raise her children. She doubted her abilities as a practitioner and was satisfied to do menial work. At the same time, the volunteers (without any teaching qualifications) acted as teachers of the children.

Thea, on the other hand, was an unmarried woman in her mid-40s. She had a BSc degree and used to have a work and an apartment. Nevertheless, she chose to resign and moved to live and work in an informal settlement as she believed this move to be a divine calling. She was confident about her professional skills and was appointed as a principal of the centre. Therefore, she was highly disappointed when her authority was disregarded by her colleagues and the volunteer who originally appointed her as a principal. However, both practitioners loved the children in their care and were devoted to their work. Both showed remarkable insight regarding the needs of the children in their respective centres and an understanding of the socio-economic conditions that hamper optimal growth and development of the children. They focused on the achievements of the children and not on their shortcomings. As Rina and Thea were the most qualified members of their respective communities, they also had to run an aftercare facility for the school children of their settlements to assist with homework.

In spite of different backgrounds, personal histories and unique personalities, four dominant themes common to the participants' narratives could be identified, including the practitioners' personal and social experiences, their experiences concerning place, their experiences with camp leadership and their experiences concerning support infrastructure. Butler-Kisber (2010:15) indicates that in qualitative research, because of the small number of participants and the contextualised nature of the research, one situation cannot be generalised to another. Therefore, the findings regarding the two participants' experiences are separately discussed.

At the same time, the various contextual systems of influence as defined by Bronfenbrenner (1979) are evident in the experiences of both Rina and Thea. From the themes that emerged from this study, it is evident that various microsystems were at play in Rina and Thea's experiences. These include the children they worked with and their colleagues with whom they interacted on a daily basis. The volunteers who established and maintained the centres and either worked as practitioner in the centre or assisted the practitioners were microsystems of the practitioners. The owner or camp manager of the two communities also served as microsystems of the practitioners. The mesosystem included the relationship between the children in the centre and the other practitioners (the colleagues of the two practitioners), between camp management and the volunteers and between their colleagues and the volunteers. From the identified themes, the parents of the children emerged as exosystem of the participants. The practitioners had to cope with the challenges of the children caused by problematic circumstances at home. The links between the volunteers and donors or sponsors were more examples of the practitioners' exosystem. Although the practitioners often did not know the donors or sponsors, they depended on their goodwill and aid to survive and to keep the doors of the centres open. The macrosystem of the participants included the deprived lifestyle of the communities and the social woes that usually accompany poverty as indicated in poverty literature, for example, Azzi-Lessing (2010), Waldfogel et al. (2010) and Jensen (2009).This, in turn, typically had an influence on the residents' parenting skills which, in turn, contributed to the behavioural problems of the children in the practitioners' care. The participant practitioners were also subject to the economic hardship of the community which affected their health and emotional well-being.

\section{Rina's narrative}

\section{Experiences concerning place}

Rina and her extended family lived in a makeshift house of corrugated iron and tents as an extension of the home. Rina was highly distressed about the fact that their house did not have electricity as she believed that this condition was to the detriment of her children. Rina and her husband regularly made plans to improve their lives. She had been working as a practitioner in the ECD centre for 4 years at the time and earned a negligible salary of R250.00 per month - a donation collected by the volunteers from a church group active in the community. Although Rina was initially very frustrated with the small size of her classroom, the room was eventually enlarged, painted and decorated by the volunteers. This resulted in the classroom being colourful, warm and inviting with overflowing toy boxes. The classroom and playground were well equipped, but the volunteer teaching the older group complained about a broken gate being a safety hazard. A child was injured when the gate fell on her. The volunteer 
had asked the self-appointed manager of the settlement to fix the gate but to no avail. She commented that he took the money donated to the centre by individuals and charities, but did nothing for the centre.

As Rina's community illegally occupied an abandoned caravan park, the sword of eviction was hanging over their heads for years. No long-term plans for the centre could thus be made.

\section{Personal and social experiences}

Rina openly expressed her love for the children in her care and demonstrated her affection towards them by hugging, kissing, carrying them and playing with them. The children had a trusting relationship with her and talked openly to her about upsetting incidents that happened at home. Rina experienced that both parents and children valued her, and she derived a sense of purpose from her work. At the same time, the work caused her distress. She talked about neglect and abuse of children and specifically remembered the severe beating of a 5 -year-old by her mother. The mother believed that her daughter took her cellphone and came to the centre to beat the child. Rina helplessly stood by, not knowing how to handle the situation. She commented that if Child Welfare had been there that day, they would have removed the child from the mother's care. Rina was at a loss on how to prevent parental maltreatment of the centre's children, neither talking to the parents nor reporting the abuse to authorities although she found abuse and neglect profoundly upsetting. However, a parent guidance workshop was offered to the community, but the mothers who enrolled were not interested to complete the programme.

Welfare indeed removed three children from their mother, an incident Rina found highly traumatic. The one sibling, a toddler, clung to Rina, screaming and did not want to let go when the social worker tried to take her. Rina interpreted this as a plea for help and that she had let the child down. As she was particularly fond of the toddler, Rina experienced this as a personal loss. A few months later the baby sister who stayed behind with the mother died. Being a mother herself, Rina had empathy with the mother and found this experience difficult to handle emotionally: 'Daai stuk kan ek nie hanteer nie' [That part I cannot handle].

\section{Experiences with camp leadership}

The camp manager decided how the centre should be run, had control over the finances of the centre and appointed and dismissed staff at the centre on a whim, which left Rina highly distraught. Rina was desperate when the volunteer working as a practitioner was told not to return to the centre. Firstly, handling the centre on her own overwhelmed Rina. Secondly, the volunteer was instrumental in securing donations to the settlement and in particular to Rina and her children. The self-appointed manager's position was undisputed, and Rina did not stand up to him when he kept on swearing at her about an issue that was none of her doing. Furthermore, she believed without a doubt that the manager and his wife always acted in the best interest of the children.

\section{Experiences concerning support infrastructure}

A salient feature of the settlement was the constant flow of donors, volunteers, loads of donations arriving at the settlement and the active involvement of outsiders supporting the community and in particular the ECD centre on a daily basis. Groups of women from surrounding neighbourhoods visited on different days to present various activities. Especially the younger group (mostly toddlers) was subject to an ever-changing stream of different women performing age-inappropriate activities. For example, a social worker indicated that her task was to teach the children shapes and colours. The children had to sit passively at tables while she repeated the names of the shapes and colours. Afterwards, the children had to watch a video of Moses and the Ten Commandments. Bored toddlers who did not pay attention were reprimanded. Rina, their teacher, was relegated to minor cleaning work and supervision of outside play. Rina indicated that she would appreciate training to be a qualified teacher. Although the volunteers had promised to enrol her for a training course a number of times, this never materialised.

Other donor organisations included a well-known auditors' firm, a group of bikers, a pharmaceutical company, famous singers and celebrities, a youth organisation and church groups. The abundance of donations often included nonnutritional sweets and snacks. Food donations were also precarious. Rina explained that the camp manager's wife prepared meals for the community, but only when she had food to prepare: '... sy kan nie kosmaak as daar niks inkom nie' [... she cannot cook if no food comes in].

\section{Thea's narrative}

\section{Experiences concerning place}

Thea's settlement on a privately-owned farm looked well maintained and peaceful from the outside. The ECD centre was next to a dam complete with floating ducks. Thea pointed out that the playground was treacherous as the dam was a drowning hazard, the road next to the playground carried heavy trucks transporting tar and on the third side of the playground was the kitchen with a donkey boiler on the outside where children could get burnt. The fact that the toddlers were busy with potty-training made matters worse, as the toilets were far from the playgrounds and the toddlers needed an adult to accompany them to the toilet. Thea regularly counted the children on the playground to make sure everyone was still safe. She referred to the situation as " $n$ nagmerrie' [a nightmare]. Thea secured a donation to have the playground fenced in, but the owner refused the request, indicating that this would spoil the appearance of the gardens. The wooden hut that served as her house did not offer her enough protection against the elements in winter, and she became very sick. The fact that she had to walk some distance to get to a toilet or shower made matters worse during winter. She felt that some children were even more exposed and talked about a family where the children slept on the veranda with a makeshift roof of plastic sheets. 
The alternative was to have children sharing the same room as their parents which Thea felt was also not desirable.

\section{Personal and social experiences}

Thea explained how she tried to juggle her responsibilities as ECD practitioner and also supervising the aftercare. She cleaned the centre and toys afterhours and over weekends and washed dishes between activities at times when she did not have a cleaner. The volunteer who set up and managed the centre expected her to offer the children worksheets to complete. She copied the worksheets by hand in the evenings as she did not have access to a photocopier and the centre could not afford to buy workbooks. Although she received a salary of R200 per week from the volunteer, this money was suspended during weeks when she was off sick. Not having money to take care of personal needs, left Thea embarrassed. Already during our first interview, Thea complained about ill-health and exhaustion. She threatened to resign, but the volunteer and representative of the NGO supporting the settlement downplayed it as mere endof-the-year exhaustion. Thea felt misunderstood as the volunteers could not see that she was overburdened. The social problems in the settlement caused Thea further undue stress, which exacerbated her ill-health.

She talked about mothers being busy with men while neglecting their children and the effect of a hostile home environment on children's learning and behaviour. The services of a social worker were suggested by Thea when asked during an interview how the centre should be managed. She realised that the community's children needed specialised social support more than educational activities. At the same time, the well-being of the settlement's children had been compromised to the extent that the removal of the children by the welfare was a real threat. She therefore advised as follows regarding the social worker: '... hoor hier, leer hier, kyk wat aangaan, maar moenie die kinders weg vat nie' [... listen here, see what is happening, but do not remove the children].

Parents were irresponsible in terms of their children's school attendance. Furthermore, they were impulsive, leaving the settlement because of minor altercations with the owner or fellow residents. Not only did they end up on the streets begging, but their children's schooling was interrupted. The families' high mobility had an effect on Thea's teaching and the learning objectives she planned for the children. Considering these challenges, Thea suggested that experts should be consulted to tailor teaching and learning objectives for the context. Notwithstanding, her work gave her a sense of purpose, and she referred to the centre as a child '(e)k het twee-en-' $n$-half jaar hierdie kleuterskool grootgemaak. En nou moet ek dit vir iemand gee wat niks omgee nie' [For two and a half years have I raised this preschool and now I have to give it to someone who doesn't care a bit].

\section{Experiences with camp leadership}

Thea's position in the centre, as well as the centre itself, fully depended on the goodwill of the owner. Thea specified that the proprietor was not confident about the centre because he believed that mothers should look after their children, which left Thea unsure about the future of the centre. At the same time, the centre was a source of income: 'Die kleuterskool bring indirek vir hulle geld van buite of in, want mense se harte word altyd sag as hulle' $n$ klomp kinders bymekaar sien' [Indirectly the preschool brings money in from outside because people's hearts soften when they see a group of children together]. The centre and the well-being of the children were not always a priority for the owner. For example, Thea's concerns about the quality of the food prepared for the centre's children and her request that school children be provided with sandwiches for school were ignored by the owner. Thea was promised a larger classroom as she had all age groups in one room - a very unsatisfactory situation. This promise was not kept, and Thea expressed her disappointment. Thea only received her own classroom when the volunteer was prepared to pay R1300.00 per month towards rent for the wooden hut. After Thea had left the settlement, the owner terminated all volunteer involvement indicating that the community could run the centre themselves according to their religious beliefs.

The owner had absolute authority over the residents and decided who could stay on the farm and who had to leave. Residents did not dare to complain and were asked to leave if they were not happy with the conditions. When a mother reported that a fellow resident molested her daughter, no action was taken. Thea believed that the owner did not want to give up on the rent that the alleged perpetrator paid for his wooden hut. Parents also feared that their children might offend the owner, which could lead to expulsion. When Thea wanted to take action against alleged child abuse when a toddler was burnt by the cigarette of a practitioner, the owner asked her to leave the settlement. He indicated that she was bad for his settlement. She explained that for the owner, it was all about the donations made to the ECD centre. Therefore, he did not want to have child abuse at his settlement made public. At the same time, Thea was strangely loyal towards the proprietor. She indicated that he gave homeless people a roof over their heads, food and hot water. Therefore, they had to be grateful towards him.

\section{Experiences concerning support infrastructure}

The dominant narrative of poor white people, and even more so of organisations and individuals supporting them, is that they do not have access to public social and financial assistance, because of the colour of their skins (Kruger 2010). Nevertheless, NGOs, charity organisations, social groups, church groups and private individuals were found to be actively involved in poor communities of predominantly white people. A medical doctor offered her services to the settlement on a monthly basis and an NGO provided a parent guidance workshop to the parents of the community. However, Thea felt that the workshop did not have any impact on their parenting skills as she described gross parental neglect. Thea talked about an advertisement posted in the kitchen offering to train residents as fitters, electricians and mechanics free of charge. Also, Thea was promised a training course by $\mathrm{Mia}^{2}$, the volunteer who set up the ECD 
centre in the settlement and actively supported and managed the centre. The promised training never materialised, which left Thea frustrated and disappointed.

The abundant donations and handouts even disturbed the social balance in the settlement as everybody wanted to work where these donations were received and distributed. This position meant that the worker had first access to the donations and could take the best before the rest was circulated to the remainder of the community. This situation led to fighting and fawning among the residents, and the most aggressive usually won the position. Unfortunately, the ECD centre was the main delivery point for the donations. Because of this, those who occupied the position of ECD practitioner were often not the most suitable to work with children. Also, the volunteer's favours and gifts to the practitioners exacerbated the discord, not only in the staff corps, but also between the staff and the rest of the community. Thea explained:

'Die ander probleem is Mia, almal wil gatkruip by haar, almal wil haar regterhand wees, en almal wil in die kleuterskool bederf word. So almal baklei, en naamskending is een van die maniere om jou daar uit te kry, die pos te kry. So, ek dink nie Mia besef hoe groot invloed het dit op hulle nie.' [The other problem is Mia' everyone wants to win her favour, everyone wants to be her right-hand woman, and everybody wants to be spoilt in the preschool. Thus, everybody is fighting, and defamation is one of the ways to get a person out of there to get the position for oneself. I don't think Mia realises what significant influence she has on them.] (Thea, practitioner, female)

Despite being appointed as a principal, Thea was never consulted regarding best practices for the particular context. Thea found this most disturbing as she read extensively on all matters regarding education. She complained:

'En as jy, as jy'n skoolhoof het, moet jy daai skoolhoof se woord kan vat bo al die gemors-stories.' [And if you, if you have a principal, you should accept the principal's word above all the other rubbish stories.] (Thea, practitioner, female)

\section{Discussion}

Rina and Thea came from different backgrounds with unique personalities and motivations for living and working in their settlements, which coloured their experiences and influenced their responses regarding their situations. Yet, a unifying thread in the four themes that emerged in the participants' narratives was that of a sense of disempowerment in the various domains of their lives and work. The participants were, for example, never enabled by the different role players active in the communities to make a meaningful difference in the lives of the children. Furthermore, they were not allowed by these role players to apply their skills, experience and insight in their daily work.

\section{Disempowering experiences concerning place}

As the practitioners were at the mercy of camp management, they had no authority to address safety hazards. However, these concerns caused undue stress as the practitioners were responsible for the children's well-being. Atmore et al. (2012) point out that safety issues are more prevalent at unregistered centres and specify the absence of secure fencing as a common safety concern.

\section{Disempowering personal and social experiences}

The high mobility of the families further disempowered the practitioners to make a significant impression on the learning and development of the children. Thea referred to children in her group who could not perform age-appropriate tasks even though they had attended pre-schools in the informal settlements where they came from, because there was no continuity in their learning. She felt that the high mobility of the community's families compromised children's school readiness, a view supported by the research findings of various scholars, for example, McCoy and Raver (2014), Brown et al. (2013) and Martin, Razza and Brooks-Gunn (2012). Children coming and going also disrupted her planning as she referred to the concert she planned for the group. Rumberger (in Porter \& Edwards 2014) refers to the 'chaos factor' in this regard as the whole group (also those children staying behind) is affected by the high mobility among low-income families. Thea remembered her frustration when she tried to put a concert together:

'Maar ja, toe het ek net weer besef jy kan nie eers'n konsertjie deurvoer nie, want jy oefen twee maande aanmekaar vir ' $n$ konsertjie en ' $n$ week voor die tyd sit jy sonder kinders.' [But yes, then I realised once again one cannot even carry through a concert, because you practise for two months non-stop for a concert, and a week before the time you are stuck with no children.] (Thea, practitioner, female)

The parents were also never consulted regarding their needs, as volunteers decided on the most suitable parent guidance programme organised by an NGO for the parents of the respective communities. It seems that the social context and parental needs of the residents were not considered when this programme was presented. The writer talks in a vernacular not familiar to the residents about her happy, close-knit family and personal possessions such as a tumble dryer and her computer.

However, various international parent guidance programmes were successfully presented to low-income parents. These include Parenting through Change and the Family Care Curriculum (Perlman et al. 2012), the Pride in Parenting intervention (Katz et al. 2011) and the Hands-On Parent Empowerment programme (Leung et al. 2009, 2011). All of these programmes identified some principles to consider in order to ensure an efficient programme regarding improved parenting. These included active participation by all involved and consideration of family and social contexts with a focus on the specific needs of the community. While some middleclass parents indicated that they found the book, Kweek kinders met karakter [Cultivate Children with Character] by Hettie Brittz (2008), on which the programme was based, helpful, the content of the book and subsequent programme was not suitable for this community. Perlman et al. (2012:406) 
contend that 'a one-size-fits-all approach to parenting programs would be inappropriate'. To conclude, this was a lost opportunity to empower not only the parents but also the ECD practitioners of the two communities, as the volunteers decided on an ill-suited programme.

\section{Disempowering experiences with camp leadership}

Not only the children's safety but also food available to the centre's children depended fully on the goodwill of camp leadership. As the camp leader had absolute authority over the community and the centres, the practitioners did not dare to complain about irregularities and illegal acts such as child abuse. This rendered them powerless to act in the best interests of the children in their care.

\section{Disempowering support infrastructure}

It seems that the negation of practitioner insight and experience in the development of an ECD programme for poor communities is a common issue. Fourie (2013) explains:

Professionals often regard themselves as the sole owners of developing wisdom and as having the monopoly of solutions which consistently underrate and under-value that capacities of local people to make their own decisions as well as to determine their priorities. (p. 61)

The fact that both participants never received promised training left them frustrated. More importantly was that the potential of quality ECD experiences to moderate the effect of poverty on children's growth potential was largely diminished. Various scholars, for example, Aguilar-Crandall and Sutterby (2011) and Roberts et al. (2011), emphasise the importance of the quality and competence of practitioners, especially of those serving impoverished communities. AzziLessing (2010) explains that quality ECD programmes can offer children raised in poverty a calm and predictable environment where they can be nurtured and stimulated, and where their parents are supported. However, the irony is that these centres lack the necessary resources to meet the high levels of need of vulnerable children and their families. Azzi-Lessing (2010) explains that low-income communities cannot afford higher school fees that would allow for expertise to meet the social and emotional needs of troubled children and to professionally support the practitioners who are often overwhelmed. Professional training was one way that the practitioners could have been empowered to address the manifold needs of the children in their care. Biersteker et al. (2016) propose teacher training, opportunities for professional development and good working conditions as indicators of quality.

Although the volunteers' assistance was misguided, they could render meaningful support. They coordinated food donations and volunteer services, for example, medical check-ups and screenings which contributed to the community's health and well-being. Sparks (2010) researched the impact of a food assistance programme for low-income pregnant women and mothers and young children and concluded that all low-income families could benefit from such a programme. Furthermore, the donations were delivered at the respective ECD centres, and the centres were used to provide medical services. Peterson et al. (2010) emphasise the role of an ECD centre in providing support services to families living in poverty. At the same time, these intervention strategies should be tailored for the context to be useful. For example, the volunteer at Rina's centre arranged a donation of R2000.00 for psychotherapy for a child. However, the number of therapy sessions was not enough and therefore did not deliver the desired results.

The involvement of the social worker in Rina's centre was yet another example of misplaced assistance. Instead of acting as a teacher for Rina's group, where she presented inappropriate activities, she could have supported parents in a context rife with social challenges. She could have provided the practitioners with moral support and practical guidance in dealing with children and families in highly taxing circumstances, both emotionally and socially. At the same time, protecting the children in their care against maltreatment and neglect is a grave predicament. The prospect of welfare intervention left the practitioners in both communities powerless. Therefore, Thea's recommendation of a collaboration between practitioners and academic experts is highly significant and should be considered.

\section{Conclusion}

This article aimed to shed light on the experiences of two ECD practitioners working and living in poor marginalised communities of predominantly white people. A more specific focus was their contexts as (dis)empowering agents based on practitioner narratives. The discourse about the marginalisation of the poor as discussed in the literature review played out in the work and lives of the two participants. They were marginalised in terms of any decision-making concerning the centres by the volunteers and campleadership, notwithstanding their professional experience and insight. This, in turn, compromised the quality of the programmes. Furthermore, compromised parenting created challenges for the children which the practitioners were not empowered to handle. The volunteers who were qualified in this regard preferred to perform the teaching tasks of the practitioners. Fear of eviction also prevented the practitioners from addressing concerns regarding the well-being of the children.

We believe that this article can make a modest contribution towards gaining a better understanding of the nature of effective support to ECD centres in impoverished and marginalised communities. The empowerment of the practitioners in these communities is particularly relevant. The experiences of the practitioners in terms of contextual disempowerment might resonate with those of their colleagues in similar impoverished communities - not only in predominantly white communities.

In order for volunteers and benefactors to make a meaningful difference in the lives of the people they are serving, they should firstly acknowledge the input of key role players. 
Secondly, practitioners should be professionally empowered to deliver a quality service for their specific context. Thirdly, the practitioners' articulated needs and challenges should be addressed. Lastly, practitioners should be empowered in their personal lives by paying them a living wage and creating dignified working and living conditions for them.

\section{Acknowledgements Competing interests}

The authors declare that they have no financial or personal relationships that may have inappropriately influenced them in writing this article.

\section{Authors' contributions}

T.K. is responsible for the research and writing of the manuscript. B.S. and P.M. supervised, gave guidance and support and edited the manuscript for final approval before submission.

\section{Data availability statement}

Data sharing is not applicable to this article as no new data were created or analysed in this study.

\section{Disclaimer}

The views and opinions expressed in this article are those of the authors and do not necessarily reflect the official policy or position of any affiliated agency of the authors.

\section{References}

Africa Forum, 2010, Study on the most marginalized populations in sub-Saharan Africa, Future Pre Press, Pretoria.

Aguilar-Crandall, M.M. \& Sutterby, J.A., 2011, 'Professional development: Change we can believe in', Advances in Early Education and Day Care 15, 155-173. https:// doi.org/10.1108/S0270-4021(2011)0000015010

Alderman, H., 2011, No small matter: The impact of poverty, shocks, and human capital investments in early childhood development, The World Bank, Washington, DC.

Angélil, M. \& Siress, C., 2012, 'The Paris Banlieue: Peripheries inequity', Journal of International Affairs 65(2), 57-67.

Atmore, E., Van Niekerk, L. \& Ashley-Cooper, M., 2012, 'Challenges facing the early childhood development sector in South Africa', South African Journal of Childhood Education 2(1), 120-139. https://doi.org/10.4102/sajce.v2i1.25

Azzi-Lessing, L., 2010, 'Meeting the mental health needs of poor and vulnerable children in early care and education programs', Early Childhood Research and Practice 12(1), viewed 14 October 2015, from http://ecrp.uiuc.edu/v12n1/azzi.html.

Berg, B.L., 2009, Qualitative research methods for the social sciences, Allyn \& Bacon, Boston, MA.

Bernanke, B.S., 2012, Early childhood education, in Speech at the Children's Defense Fund National Conference, Cincinnati, $\mathrm{OH}$, July 24, viewed 02 October 2015, from $\mathrm{http}: / / w w w . f e d e r a l r e s e r v e . g o v /$ newsevents/speech/bernanke20120724a.htm.

Biersteker, L., Dawes, A., Hendricks, L. \& Tredoux, C., 2016, 'Center-based early childhood care and education program quality: A South African study', Early Childhood Research Quarterly 36, 334-344.

Brittz, H., 2008, Kweek Kinders met Karakter: Hoe om elke boompie na sy aard te buig, Carpe Diem Media, Vanderbijlpark.

Bronfenbrenner, U., 1979, Ecology of human development: Experiments by nature and design, Harvard University Press, Cambridge, MA.

Brooks-Gunn, J. \& Duncan, G.J., 1997, 'The effects of poverty on children', The Future of Children 7(2), 55-71. https://doi.org/10.2307/1602387

Brown, E.D., Ackerman, B.P. \& Moore, C.A., 2013, 'Family adversity and inhibitory control for economically disadvantaged children: Preschool relations and associations with school readiness', Journal of Family Psychology 27(3), 443-452. https://doi.org/10.1037/a0032886

Butler-Kisber, L., 2010, Qualitative inquiry: Thematic, narrative and arts-informed perspectives, Sage, Thousand Oaks, CA.
Caine, V., Estefan, A. \& Clandinin, D.J., 2013, 'A return to methodological commitments: Reflections on narrative inquiry', Scandinavian Journal of Educational Research Reflections on narrative inquiry', Scandinavian Journal of Education
57(6), 574-586. https://doi.org/10.1080/00313831.2013.798833

Christensen, L.B., Johnson, R.B. \& Turner, L.A., 2015, Research methods, design, and analysis, 12th edn., Pearson, Essex.

Clandinin, D.J. \& Murphy, M.S., 2007, 'Looking ahead: Conversations with Elliot Mishler, Don Polkinghorne, and Amia Lieblich', in D.J. Clandinin (ed.), Handbook of narrative inquiry: Mapping a methodology, pp. 632-650, Sage, Thousand Oaks, CA.

Clandinin, D.J. \& Rosiek, J., 2007, 'Mapping a landscape of narrative inquiry: Borderland spaces and tensions', in D.J. Clandinin (ed.), Handbook of narrative inquiry: Mapping a methodology, pp. 35-76, Sage, Thousand Oaks, CA.

Creswell, J.W., 2013, Qualitative inquiry \& research design: Choosing among five approaches, 3rd edn., Sage, Thousand Oaks, CA.

Dawes, A., Biersteker, L. \& Hendricks, L., 2012, Sombambisana initiative: Partner evaluation report, llifa Labantwana, Cape Town.

Dewey, J., 1938, Education \& experience, in Kappa Delta Pi, viewed 27 April 2013, from $\mathrm{http}: / /$ ruby.fgcu.edu/courses/ndemers/colloquium/experienceducationdewey.pdf.

Ebrahim, H.B., Killian, B. \& Rule, P., 2011, 'Practices of early childhood development practitioners for poor and vulnerable children from birth to four years in South Africa', Early Child Development and Care 181(3), 387-396. https://doi.org/ 10.1080/03004430903392602

Elliot, J., 2005, Using narrative in social research: Qualitative and quantitative approaches, Sage, Thousand Oaks, CA.

Fourie, J.E., 2013, 'Early childhood education in South African townships: Academics accepting the challenge to empower early childhood development practitioners', Journal of Social Sciences 36(1), 59-68. https://doi.org/10.1080/09718923.2013. 11893173

Grunewald, R., 2015, 'Early childhood native American language immersion programs: A promising approach to school preparation, economic opportunity and language preservation', in National Congress of American Indians 10th Annual Tribal Leader/ Scholar Forum, St. Pauls, Minnesota, 30 June, viewed 02 September 2015, from https://www.minneapolisfed.org/publications/special-studies/early-childhooddevelopment.

Heckman, J.J., 2013, Giving kids a fair chance, The MIT Press, Cambridge, MA.

Hollway, W. \& Jefferson, T., 2008, 'The free association narrative interview method', in L.M. Given (ed.), The SAGE encyclopedia of qualitative research methods, in L.M. Given (ed.), The SAGE en
pp. 359-360, Sage, Sevenoaks, CA.

Huchzermeyer, M. \& Karam, A., 2006, 'The continuing challenge of informal settlements: An introduction', in M. Huchzermeyer \& A. Karam (eds.), Informal settlements: A perpetual challenge? pp. 1-18, UCT Press, Cape Town.

Jensen, E., 2009, Teaching with poverty in mind: What being poor does to kids' brains and what schools can do about it, ASCD, Alexandria.

Jovchelovitch, S. \& Bauer, M.W., 2000, Narrative interviewing, LSE Research Online, London, viewed 23 April 2014, from http://eprints.Ise.ac.uk/2633.

Katz, K.S., Jarrett, M.H., El-Mohandes, A.A.E., Schneider, S., McNeely-Johnson, D. \& Kiely, M., 2011, 'Effectiveness of a combined home visiting and group intervention for low income African American mothers: The Pride in Parenting Program' Maternal and Child Health Journal 15(S1), S75-S84. https://doi.org/10.1007/ s10995-011-0858-x

Kholowa, F. \& Rose, P., 2007, 'Parental of policy maker misunderstandings? Contextual dilemmas of pre-schooling for poverty reduction in Malawi', International Journal of Educational Development 27, 458-472. https://doi.org/10.1016/j.ijedudev. 2006.10.007

Knafo, T., 2016, 'Experiences of practitioners in early childhood development centres in impoverished and marginalised predominantly white communities', M.Ed. dissertation, University of South Africa, Pretoria.

Kruger, C., 2010, 'Armoede het nie velkleur', Rapport, 4 April 2010.

Leung, C., Tsang, S. \& Dean, S., 2011, 'Outcome evaluation of the Hands-On Parent Empowerment (HOPE) Program', Research on Social Work Practice 21(5), 549-561. https://doi.org/10.1177/1049731511404904

Leung, C., Tsang, S., Dean, S. \& Chow, P., 2009,'Development and pilot evaluation of the Hands On Parent Empowerment (HOPE) project - A parent education programme to establish socially disadvantaged parents as facilitators of preschool children's learning', Journal of Children's Services 4(1), 21-32. https://doi. org/10.1108/17466660200900003

Lincoln, Y.S. \& Guba, E.G., 1985, Naturalistic Inquiry, Sage, Beverly Hills, CA.

Martin, A., Gardner, M. \& Brooks-Gunn, J., 2012, 'Specifying the links between household poverty chaos and preschool children's development', Early Child Development and Care 182(10), 1247-1263. https://doi.org/10.1080/03004430. 2011.605522

Martin, A., Razza, R.A. \& Brooks-Gunn, J., 2012, 'Specifying the links between household chaos and preschool children's development', Early Child Development and Care 182(10), 1247-1263. https://doi.org/10.1080/03004430.2011.605522

McCoy, D.C. \& Raver, C.C., 2014, 'Household instability and self-regulation among poor children', Journal of Children and Poverty 20(2), 131-152. https://doi.org/10. 1080/10796126.2014.976185

McMillan, J.H. \& Schumacher, S., 2010, Research in education: Evidence- based inquiry, 7th edn., Pearson Education, Boston, MA.

Mustard, J.F., 2007, 'Experienced-based brain development: Scientific underpinnings of the importance of early child development in a global world', in E.M. Young \& L.M. Richardson (eds.), Early child development: From measurement to action, pp. 43-84, The World Bank, Washington, DC.

Perlman, S., Gewirtz, A., Cowan, B., Haskett, M. \& Stokes, L., 2012, 'Promoting positive parenting in the context of homelessness', American Journal of Orthopsychiatry 82(3), 402-412. https://doi.org/10.1111/j.1939-0025.2012.01158.x 
Peterson, C.A., Mayer, L.M., Summers, J.A. \& Luze, G.J., 2010, 'Meeting needs of young children at risk for or having adisability', Early Childhood Education Journal young children at risk for or having adisability', Early Childhood
$37(6), 509-517$. https://doi.org/10.1007/s10643-010-0375-3

Pharoah, R., 2008, The situation of poor white youth: An assessment of context and interventions, Situation of poor white youth comprehensive report, Research conducted on behalf of Umsobomvu Youth Fund, Unpublished.

Porter, S. \& Edwards, M., 2014, 'Household and economic factors associated with geographic and school mobility among low-income children', Journal of Children and Poverty 20(2), 111-113. https://doi.org/10.1080/10796126.2014.979140

Ridge, T., 2011, 'The everyday costs of poverty in childhood: A review of qualitative research exploring the lives and experiences of low-income children in the U.K.' Children and Society 25(1), 73-84. https://doi.org/10.1111/j.1099-0860.2010. 00345. $x$

Roberts, J., Frye, A., Love, M.L. \& Van Thiel, L., 2011, 'Building professional development for urban public preschools: Experiences and reflections', Advances in Early Education and Day Care 15, 91-128. https://doi.org/10.1108/S02704021(2011)0000015008

Šabić, D., Knežević, A., Vujadinović, S., Golić, R., Milinčić, M. \& Joksimović, M., 2013 'Belgrade slums - Life on the margins of Serbian Society', Trames 17(1), 55-86. https://doi.org/10.3176/tr.2013.1.03

Saldaña, J., 2013, The coding manual for qualitative researchers, 2nd edn., Sage Thousand Oaks, CA.

Schurink, W., Fouché, C.B. \& De Vos, A.S., 2011, 'Qualitative data analysis and interpretation', in A.S. De Vos, H. Strydom, C.B. Fouché \& C.S.L. Delport (eds.), Research at grass roots for the social sciences and human service professions, 4 th Research at grass roots for the social scien
edn., pp. 397-423, Van Schaik, Pretoria.

Shonkoff, J.P. \& Phillips, D.A., 2000, From neurons to neighborhoods: The science of early childhood development, National Academy Press, Washington, DC.
Solidarity Helping Hand, 2010, Gesigte van Afrikanerarmoede, viewed 14 October 2012 from http://blog.solidariteitbeweging.co.za/files/2010/04/Afrikaner-Armoedeoptimized1.pdf.

Sparks, P.J., 2010, 'Childhood morbidities among income- and categorically-eligible WIC program participants and non-participants', Journal of Children and Poverty 16(1), 47-66. https://doi.org/10.1080/10796120903575093

Statistics South Africa, 2014, The South African MPI: Creating a multidimensional poverty index using census data, Statistics South Africa, Pretoria.

Statistics South Africa, 2015, Methodological report on rebasing of national poverty lines and development of pilot provincialpoverty lines, Technical Report, 03-10-11, Statistics South Africa, Pretoria.

Strydom, H., 2011, 'Ethical aspects of research in the social sciences and human service professions', in A.S. De Vos, H. Strydom, C.B. Fouché \& C.S.L. Delport (eds.), Research at grass roots for the social sciences and human service professions, 4th edn., pp. 113-141, Van Schaik, Pretoria.

Strydom, H. \& Delport, C.S.L., 2011, 'Sampling and pilot study in qualitative research', in A.S. De Vos, H. Strydom, C.B. Fouché \& C.S.L. Delport (eds.), Research at grass roots for the social sciences and human service professions, 4th edn., pp. 390-396, Van Schaik, Pretoria.

United Nations, 2015, Sustainable development goals, viewed 28 September 2015, from http://www.un.org/sustainabledevelopment/sustainable-development-goals/.

Van der Vyver, S., 2012, 'An early childhood development programme in a rural settlement community', Unpublished M.Ed. dissertation, University of Johannesburg Johannesburg.

Waldfogel, J., Craigie, T. \& Brooks-Gunn, J., 2010, 'Fragile families and child well-being', The Future of Children 20(2), 87-112. https://doi.org/10.1353/foc. 2010.0002 